\title{
Length-weight relationships Silver barb (Barbonymus gonionotus) in Mamberamo River, Papua
}

\author{
Mirna Dwirastina ${ }^{1,2^{*}}$, Marson $^{1}$ \\ ${ }^{1}$ Researcher of Institute Inland Fisheries and Extension, Indonesia \\ ${ }^{2}$ Researcher Inland Fisheries Resources Development and Management Department, Indonesia
}

\begin{abstract}
There are big rivers in Papua province, one of which is the Mamberamo River. The Mamberamo River, known as the Amazon of Indonesia, has very high biodiversity. Silver barb is one of the fish caught in the Mamberamo River. Silver barb is an adaptable fish, has many types and varies. Variations in Silver barb are caused by interactions with the environment as well as isolation mechanisms. This research explains the relationship between weight-length and condition factors Silver barb in Mamberamo River, Papua. The research location consists of four observation stations: Kali Merah, Kerumi, Telaga, and Sungai Putus. Sampling was carried out in February, May, August, and October 2016. The research method used was a survey using an enumerator and analysis using the LAM (linear allometric) model. The results showed that Silver barb growth was allometric negative in February and October, but in May and August, growth was allometric positive. The factor conditions for the Silver barb range 1.014-1.02.
\end{abstract}

\section{Introduction}

One of the countries whose almost all of its territory is water is the state of Indonesia. The territorial waters consist of two areas, namely freshwater or inland public waters and salty waters. Freshwaters include rivers, reservoirs, and lakes. Indonesia is part of the Southeast Asian region which has a large area of public waters. Indonesia is a country that has a high and diverse diversity of freshwater fish, which is around 1247 species [1-3]. Rivers are freshwater waters. One of the major rivers in Indonesia, the Mamberamo River, which has a length of $\pm 670 \mathrm{~km}$, is located south of the Foja Mountains, Sarmi district [4]. The catchment area in the river is $138,887 \mathrm{~km}^{2}$. The people's livelihood is farming and hunting.

One type of freshwater fish found in these waters is Silver barb (Barbonymus gonionotus). [5] Barbonymus is one of the fish caught in the Mamberamo River, Papua. Various studies have stated that Barbonymus is high biodiversity, adaptable and varied [6, $7]$. This is supported by research [8,9] which says that variations in fish species are caused by environmental interactions in the life cycle and isolation mechanisms. [10,12] explained that Barbonymus is an introduced fish named Barbonymus gonionotus [13]. The

\footnotetext{
${ }^{*}$ Corresponding author: mirna.rastina@gmail.com
} 
characteristics of Barbonymus are silver, the color of the scales on the back is darker, and the color of the scales on the belly is white. The base of the scales is gray with fins [14], comparing Barbonymus gonionotus with Tengadak fish (Barbonymus schwanenfeldii) from West Java through RAPD (Random Amplified Polymorphism DNA) markers, showing that the two fish are very different. [15] Explained that research in the Gajah Mungkur Barbonymus reservoir can grow and develop by utilizing ecological niches and an abundance of aquatic plants. [16] Barbonymus fish live in freshwaters, lowlands, and even highlands with a temperature range of $25-30^{\circ}$. Habitat Barbonymus lives in rivers, lakes, reservoirs, and rivers. The distribution area includes Sumatra, Sulawesi, and Java.

Mamberamo River research has not been done much. Observation of fisheries' biology, weight, and length is one of the critical information. Research [17] on selectivity determining fishing gear is a tool that catches fish of the appropriate size. [18, 19] Explained that the correlation between weight and length aims to assess the variation of fish weight and length are used as markers of obesity, health, productivity, and physiological condition including gonadal development. The weight and length of the fish are used as markers of health, obesity, productivity, and physiological conditions in gonadal development [20] stated the correlation analysis between weight and length is useful estimating the condition factor (Index of plumpness) for the growth process, namely comparing the health condition of the fish population relative to certain individuals. The research informs the relationship between weight and length, condition factors Silver barb (Barbonymus gonionotus) in Mamberamo river, Papua.

\section{Material and methods}

\subsection{Location and time research}

The study was conducted in February, May, August, and October 2016 on the Mamberamo River (Fig. 1). Determination of the location by purposive sampling [21] follows the differences in microhabitat (Table 1). There are four sampling points, namely Sungai Putus, Kali Merah, Kerumi and Telaga

Table 1. Sampling point of sampling.

\begin{tabular}{|c|c|c|}
\hline $\begin{array}{l}\text { Name } \\
\text { station }\end{array}$ & Coordinate & Information \\
\hline $\begin{array}{l}\text { Kali Merah } \\
\text { station }\end{array}$ & $\begin{array}{l}\text { S } 03^{\circ} 44,37.8^{\prime} \\
\text { E } 140^{\circ} 18.55 .5\end{array}$ & $\begin{array}{l}\text { The flow of the Mamberamo River tributary with } \\
\text { blackish watercolor }\end{array}$ \\
\hline Kerumi station & $\begin{array}{l}\text { S } 03^{\circ} 44.389^{\prime} \\
\text { E } 140^{\circ} 17.882^{\prime}\end{array}$ & The flow of a creek that is overgrown with trees. \\
\hline Telaga station & $\begin{array}{l}\text { S } 03^{\circ} 43,984^{\prime} \\
\text { E } 140^{\circ} 18.192\end{array}$ & $\begin{array}{l}\text { The type of river water that does not flow and the } \\
\text { penetration of incoming sunlight is very small. }\end{array}$ \\
\hline S.Putus station & $\begin{array}{l}\text { S } 03^{\circ} 42.861^{\prime} \\
\text { E } 140^{\circ} 16.799^{\prime}\end{array}$ & $\begin{array}{l}\text { Mamberamo river tributary flow will be connected to } \\
\text { the main river when the water rises/is high. }\end{array}$ \\
\hline
\end{tabular}




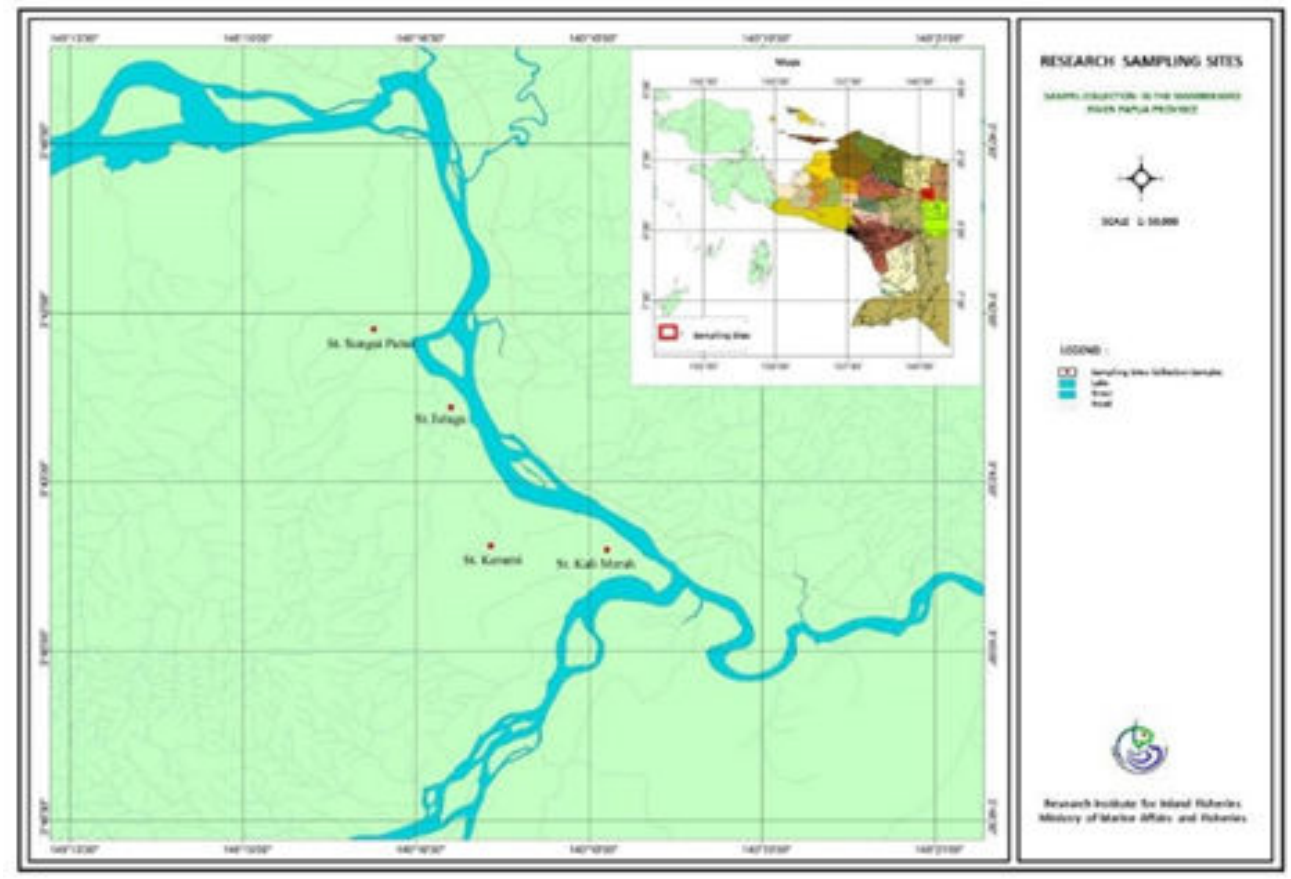

Fig.1. Research location on the Mamberamo River, Papua.

\subsection{Research methods}

The research used a survey method. Fishing gear experiments using nets of 1, 1.5, 2, 2.5, 3, $3.5,4$, and 5 inches. The installation of the lifting equipment is carried out for one night starting from the afternoon and lifting the net in the morning. The gill nets are installed by cutting the Mamberamo tributaries to maximize the catch and get all sizes of fish.

\subsection{Data analysis}

Data analysis used the LAM (linear allometric) model, which is a method by calculating parameters $a$ and $b$. Parameters $a$ and $b$ were obtained from the measurement of the weight and length of the fish.

According to research [22], correction of bias on changes in the average weight parameter of the logarithm aims to estimate the weight of fish in the length parameter with the allometric equation:

Information:

$$
\mathrm{W}=\mathrm{a} \mathrm{L}^{\mathrm{b}}
$$

$\mathrm{W}=$ the weight $(\mathrm{g})$

$\mathrm{L}=$ the total length $(\mathrm{mm})$,

$\mathrm{a}$ and $\mathrm{b}=$ parameters.

Factor condition analysis of weight relative $(\mathrm{Wr})$ and the coefficient $(\mathrm{K})$ of the condition factor used as material to assess the individual condition factors. According to [23], the relative weight with the equation: 


$$
\mathrm{Wr}=(\mathrm{W} / \mathrm{Ws}) \times 100
$$

Information:

$\mathrm{Wr}=$ weight relative,

$\mathrm{W}=$ weight of each fish

Ws is the predicted weight standard of the sample same. This is because it is calculated from merger weight and length regression through the distance between species, with the equation:

$$
\mathrm{Ws}=\mathrm{a} \mathrm{L}^{\mathrm{b}}
$$

According to research [24] coefficient condition Fulton (K) by the equation:

Information:

$$
\mathrm{K}=\mathrm{WL}^{-3} \times 100
$$

$\mathrm{K}$ is the factor condition,

$\mathrm{W}$ is the weight $(\mathrm{g})$,

$\mathrm{L}$ is length $(\mathrm{mm})$, and -3 is length coefficient to ensure that the value of $\mathrm{K}$ tends to be 1

\section{Results and discussion}

\subsection{Results}

Based on 2016 research, the catch in the Mamberamo River is Silver barb (Barbonymus gonionotus). The morphology of Barbonymus can be seen in Fig. 2.

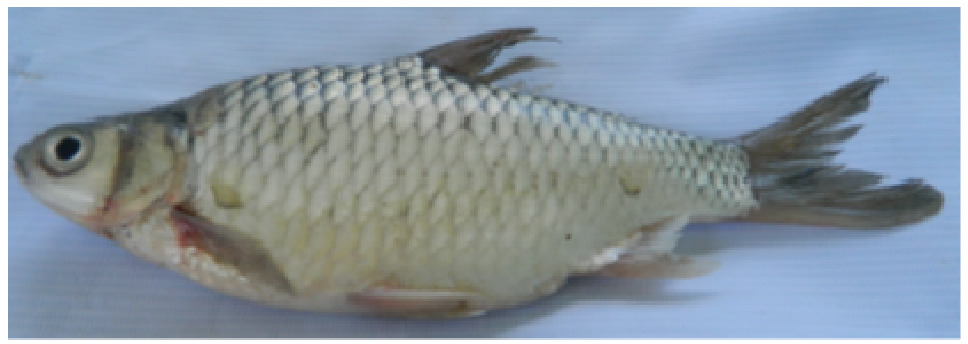

Fig. 2. Barbonymus gonionotus (Bleeker, 1849).

The results of fishing in February obtained 96 fish. There are 7 species: Systomus rubripinnis, Barbonymus gonionotus, Chilatherina fasciata, Oreochromis mossambicus, Glossamia aprion, Cyprinus carpio and Pristolepis sp. fish. The catch in June found 252 fish. The number of fish species obtained was ten types of fish consisting of Bagiridae sp., Orechromis fasciata, Systomus rubripinnis, Barbonymus gonionotus, Chilatherina fasciata, Channa sriata, Clarias sp. While the results of catching in August obtained 124 fish. The results of the October capture found 92 fish. However, some of the fishing results that are often found are Barbonymus. The results of the October capture found 92 fish. Of the most caught is Silver barb. The relationship between the length and weight of the Silver barb fish can be seen in Fig 3, and the condition factor can be seen in Fig 4. 

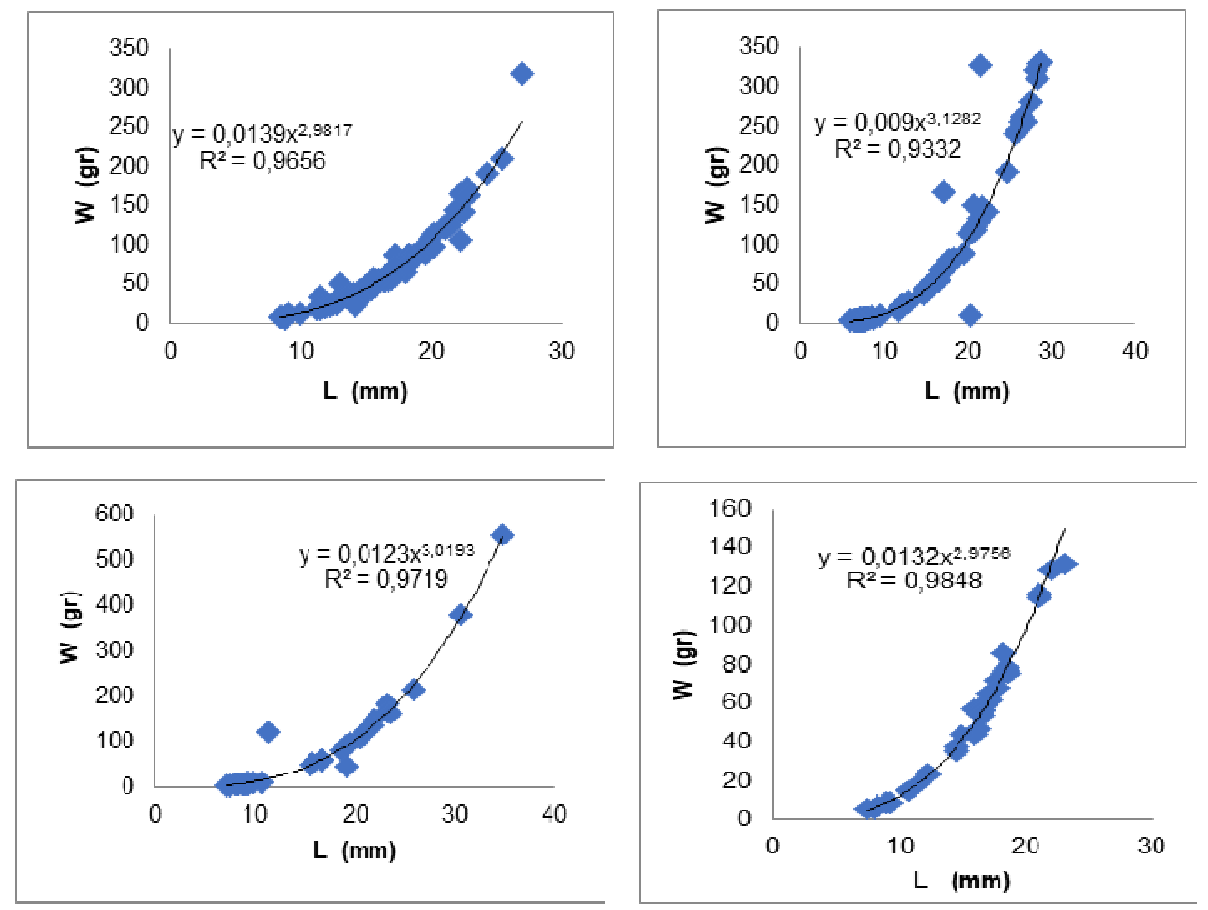

Fig. 3. The relationship weight and length of Silver barb (Barbonymus gonionotus) in Mamberamo River.

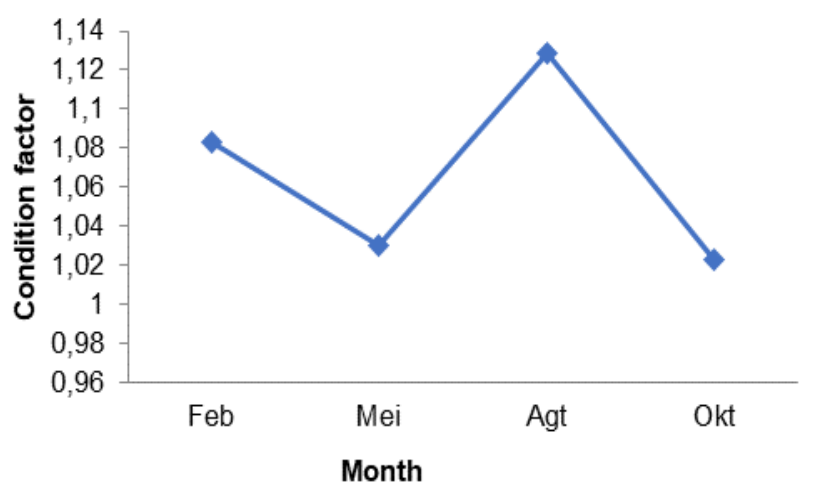

Fig. 4. Condition Factor of Silver barb (Barbonymus gonionotus).

\subsection{Discussion}

Analysis of the weight and length of Barbonymus found that the relationship between weight and length in February of Barbonymus was negative allometric because values $b<3$, May and August were because $b>3$, October was allometric negative (Fig. 2 and Table 2). [25] Explained that the relationship between weight and length is a relative growth that can change over time. 
Table 2. Growth patterns Silver barb fish in Mamberamo River.

\begin{tabular}{lclllll}
\hline \multirow{2}{*}{ Month } & \multicolumn{5}{c}{ Relationship Parameters } & \multirow{2}{*}{ Growth Patterns } \\
\cline { 2 - 5 } & $\mathrm{N}$ & $\mathrm{a}$ & $\mathrm{b}$ & $\mathrm{R}^{2}$ & \\
\hline February & 84 & 0.013 & 2.981 & 0.970 & Negative Allometric \\
May & 99 & 0.009 & 3.128 & 0.970 & Positive Allometric \\
Augustus & 39 & 0.012 & 3.019 & 0.947 & Positive Allometric \\
October & 35 & 0.013 & 2.975 & 0.994 & Negative Allometric \\
\hline
\end{tabular}

[26] The relationship between length and weight of fish can be seen from the constant $b$. If $b$ equals $3(b=3)$, then the relationship that will be formed is isometric, i.e., the increase in length is balanced with weight. Otherwise, if $b$ is not equal to 3 ( $b \# 3$ ), then it is allometric, i.e., if $\mathrm{b}$ is less than $3(\mathrm{~b}<3)$, it is negative allometric, i.e., skinny fish where the length gain is faster than weight, but if $b$ greater $3(b>3)$, then the positive allometric value is positive where the fish category plump because weight gain is faster with body length. Research on tetet fish was conducted [35] at Mayangan beach, where the relationship between length and weight is positive allometric because $b>3$. According to [27], the coefficient of $b$ is influenced by living habits, where active swimmers have a lower $b$ value than passive swimming fish. All of this is related to the amount of energy spent in movement and growth activities. Research [28] describes the closeness of the parameters of weight and length, indicating the value of the correlation coefficient (r) obtained. If $r$ is close to one, then the relationship between the two variables is strong, showing a high correlation, but if $r$ is close to zero, both are weak/or almost non-existent. [29] Explained that as R2 approaches 1, the length of the fish increases with increasing body weight. [30] ; [24] explained that fish with more extended sizes tend to live longer, have lower growth rate coefficients, and vice versa, and the difference in the value of $b$ is caused by differences in the number and types of fish observed. Based on [36] research on the length and weight of Selar fish with a coefficient of $b$ with a value of 2.71, the growth pattern is categorized as negative allometric

[31] Analysis of the weight and length of a population is applicable, namely, predicting the weight of a type of fish from the length of the fish. This is to determine the biomass of the fish population. [32] The calculation of the length of this weight can be estimated from the length of the fish or vice versa, information about fish regarding growth, elasticity, and environmental changes. Fish growth is influenced by several factors, namely internal factors (heredity, sex, parasites, resistance to disease, and the ability to utilize food) and external factors (food, temperature, and physical and chemical factors) [32].

The value of the condition factor of the Silver barb can be seen in Fig. 4. The results of the study state that the value of the condition factor every month is not much different. The highest condition factor value in August was 1.12, and the lowest in October was 1.02.

This is supported by [36] the value of the condition factor of Selar fish ranges from 1.001 1.19 , where it is stated that the fish are still in good condition [31]. [19, 33] the factors that affect the availability of food and the density of predators, the value of the condition factor is also influenced by the biotic and abiotic factors of the waters and whether or not the waters are. According to [32], the condition factor depends on the number of organisms present, natural conditions, food availability, and aquatic environmental conditions. The higher the condition factor indicates the suitability of the fish to its environment. Based on [34] influenced by the environment, condition factors are also affected by physiological conditions, especially reproductive reproduction. The condition factor value tends to increase with the higher gonadal maturation. The more mature the gonads will increase the overall body weight. This causes the condition factor value to increase [35]. 


\section{Conclusion}

Based on the research, the following conclusions are drawn:

a. Parameters of weight relationship of Silver barb (Barbonymus gonionotus) in February and October were negative allometric while May and August were positive allometric.

b. The condition factor of Silver barb (Barbonymus gonionotus) in the Mamberamo River ranges from 1.12-1.02, indicating even the condition is still in good condition.

\section{References}

1. Budiman, A.J. Arief, A.H.Tjakrawidjaya, J. Iktiologi Indones. 2, 51 (2002)

2. R. Froese, J. Appl. Ichthyol. 22, 241 (2006)

3. S.J. Richards, S. Suryadi, RAP Bul of Biol Assessment 25 (2002)

4. M. Dwirastina. D. Atminarso, JIPK 13, 38 (2021)

5. D. Atminarso, A. Wibowo, Marson, M. Dwirastina, Apriyadi, Lap Teknis (in Bahasa Indonesia) (BPPPU, Palembang, 2016)

6. Y.R. Widyastuti, T. Hutami, Pros. Sem. Nat. Ikan. VI, 581 (2007)

7. K. Purnomo, E.S. Kartamihardja, JPPI. 11, 1 (2005)

8. Indonesia Government, Number 58 of 2017 about National Strategic Projects (2003)

9. H. Ayyubi, A. Budiharjo, Sugiyarto, Sem Nas Pend Bio and Saintek, 3222 (2018)

10. M. Kottelat, J.A. Whitten, N. Kartikasari, S. Wiryoatmojo, Freshwater fishes of Western Indonesia and Sulawesi (Periplus, Hongkong,1993)

11. H. Susanto, Tawes fish hatchery and enlargement business (in Bahasa Indonesia) (Penebar Swadaya, Jakarta, 2000)

12. A.D. Utomo, S. Adjie, N. Muflikah, A.Wibowo, JPPI. 12, 89 (2006)

13. P. Bleeker, Verh. Batav. Genootsch. Kunsten, 23, 1(1849)

14. I.I. Kusmini, Mulyasari, A.Widiyati, E. Nugroho, Pros Sem Nasio Tahun VI (2009)

15. K. Purnomo, JPPI. 6, 16 (2000)

16. S. Aida, Pros Sem Nasio Ikan ke-8, 251 (2015)

17. I.G.S. Merta, JPPL. 73, 35 (1993)

18. T.J. Richter, N. Am. J. Fish Manag. 27936 (2007)

19. B.G. Blackweel, M.L. Brown. D.W. Willis, Rev. Fish. Sci. Aquac. 8, 1 (2000)

20. W.H. Everhart. W.D. Youngs, Principles of fishery science. $2^{\text {nd }}$ ed. (Comstock Publishing Associates, London, 1981)

21. C. Hadiwigeno, General water management technical guidelines for fisheries development (in Bahasa Indonesia) (Puslitbangkan, Jakarta, 1990)

A. De Robert. K. William. Trans. Am. Fish. Soc. 137, 707 (2008)

22. A.L. Rypel, T.J. Richter, N. Am. J. Fish Manag. 28, 1843 (2008)

23. H. Okgerman, Int. J. Zool. Stud. 1, 6 (2005)

24. M. Nuzapril, Widyorini, N. Afiati, Maquares 2, 18 (2013)

25. M.I. Effendie, Fishery biology (in Bahasa Indonesia) (Yayasan Pustaka Nusantara, Yogyakarta, 2002)

26. Z.A. Muchlisin, M. Musman, M.N. S. Azizah, J. Appl. Ichthyol. 26, 949 (2010)

27. R.E. Walpole, Introduction to Statistics (PT Gramedia Pustaka Utama, Jakarta, 1995) 
28. F. Afidah, K.M.A. Nugraha, W. Nuryaninda, Pros Sem Nasio Universitas Tidar, 154 (2019)

29. A. Said, Neptunus 14, 15 (2007)

30. M.I. Effendie. Biologi Perikanan (in Bahasa Indonesia) (Yayasan Pustaka Nusantara, Bogor, 1997)

31. B. R. Murphy, D.W. Willis, T.A. Springer, Fish. 16, 30 (1991)

32. Z.A. Muchlisin, Z.A, A. Muhadjier, Zulkarnaini, S. Purnawan, S.H.Cheng. I. Setiawan. Bionatura 16, 72 (2014).

33. S.B.A. Omar, Master Thesis, Bogor (ID): IPB University (2002)

34. M.F. Rahardhjo, JIPPI. 15, 140 (2008)

35. P.S. Ibrohim, JITKT 9, 577 (2017) 